\title{
LANDSCAPE TREE CULTIVAR PREFERENCES IN IOWA, U.S.
}

\author{
by Jeffery K. Iles ${ }^{1}$ and Anna M. Vold ${ }^{2}$
}

\begin{abstract}
A survey questionnaire was mailed to all 142 active members of the Iowa Nursery and Landscape Association to characterize landscape tree cultivar preferences among greenindustry professionals and their clients. Respondents identified Acer rubrum 'Franksred' (Red Sunset ${ }^{\circledR}$ red maple), Acer saccharum 'Green Mountain' (sugar maple), Acer platanoides 'Pond' (Emerald Lustre ${ }^{\mathrm{TM}}$ Norway maple), Acer $\times$ freemanii 'Jeffersred' (Autumn Blaze ${ }^{\circledR}$ Freeman maple), Fraxinus americana 'Junginger' (Autumn Purple ${ }^{\circledR}$ white ash), Fraxinus pennsylvanica 'Patmore' (green ash), Gleditsia triacanthos var. inermis 'Skycole' (Skyline ${ }^{\circledR}$ honeylocust), Tilia americana 'Redmond' (American linden), and Tilia cordata 'PNI 6025' (Greenspire ${ }^{\circledR}$ littleleaf linden) as the best-selling cultivars within nine species of trees. Betula nigra 'Cully' (Heritage ${ }^{\circledR}$ river birch) and Malus 'Prairifire' (crabapple) were identified as the bestselling cultivars in their respective genera. Considering all landscape trees sold in Iowa, our respondents identified Acer $\times$ freemanii 'Jeffersred' (Autumn Blaze ${ }^{\circledR}$ Freeman maple) as the overall best-selling selection. Overuse of these popular selections, however, could be problematic should any prove susceptible to serious, health-threatening insects, diseases, or abiotic disorders.
\end{abstract}

Key Words. Survey questionnaire; plant material trends; genetic diversity; tree preferences.

To satisfy the dynamic needs of their large and diverse clientele base, growers, retailers, designers, and installers of landscape plants must become well acquainted with current plant material trends and have some understanding of what will be popular in the future. According to Fromherz (1999), you must be able to predict what your customers need before they need it, but predicting which shade or flowering tree species or cultivar will be in demand in 10 , or even 2, years from now is a daunting, if not impossible, task. For example, Collins (1984), speaking at the annual convention of the Iowa Nurserymen's Association in 1983, suggested red maples (Acer rubrum) 'Bowhall' and 'Paul E. Tilford' as worthy additions to the Iowa plant palette. Unfortunately, these cultivars never rose above curiosity status, having been outperformed in the intervening 20 years by several other red maple selections. Others, like thornless cockspur hawthorn (Crataegus crusgalli var. inermis), were introduced (Dirr 1975), rediscovered (Iles and Widrlechner 1992) and overplanted, and now are in the process of being purged from recommended plant lists because debilitating insect and disease problems have tarnished its reputation. Still others have been rushed to the marketplace without adequate field testing, exiting almost as quickly after being exposed as either unremarkable or inferior to tree selections currently available (Dirr and Lindstrom 1989).

Gauging current market demand for shade and flowering tree species and cultivars is somewhat easier. And although this information gives but a snapshot of what is popular today, it can be useful for predicting short-term, and occasionally, longer-term plant selection preferences. Oregon tree growers, by virtue of their commanding hold on, and knowledge of, the Iowa shade and flowering tree market, can provide useful information about current sales trends (Rafter 2002). Therefore, when Oregon growers identify 'Commemoration', 'Legacy', and 'Green Mountain' as their best-selling sugar maple (Acer saccharum) cultivars, most Iowa green-industry professionals probably nod in agreement. Yet, when other Oregon growers highlight or endorse tree selections that have failed to perform with distinction in the continental climate of the upper Midwest, ('October Glory' red maple, for example), knowledgeable retailers and growers become understandably uneasy and somewhat suspicious with prognostications issued from the Northwest. Clearly, alternate and locally derived sources of information about shade and flowering tree usage trends are needed to help nursery and landscape professionals formulate and validate their plant material selection decisions.

Because we have very little current information characterizing landscape tree usage trends in Iowa, we initiated a study among nursery and landscape professionals to identify the most popular tree selections within several important species and genera.

\section{MATERIALS AND METHODS}

Data were collected using a mail questionnaire. Survey questionnaires were sent by first-class mail to all 142 active members (firms and businesses) of the Iowa Nursery and Landscape Association on November 18, 2002. Mailed questionnaires included a cover letter explaining the objective of the research and instructions for returning the completed questionnaire. INLA members were assured their individual responses would be held in confidence but would be presented in summary form.

The questionnaire contained 14 numbered questions in closed-end format requesting business-related demographic information and soliciting respondents' perceptions about 
which tree cultivars were the best sellers within nine species: red maple (Acer rubrum), sugar maple (Acer saccharum), Norway maple (Acer platanoides), Freeman maple (Acer $\times$ freemanii), white ash (Fraxinus americana), green ash (Fraxinus pennsylvanica), thornless honeylocust (Gleditsia triacanthos var. inermis), American linden (Tilia americana), and littleleaf linden (Tilia cordata), and two genera: birch (Betula spp.) and crabapple (Malus spp). Respondents were asked to consider trees their customers purchase and their own preferences when answering each of the questions. Two additional questions in open-end format allowed respondents to list their top five best-selling tree selections and to identify other tree selections popular with their clients.

\section{RESULTS AND DISCUSSION}

Questionnaires were received from 78 firms (54.9\% response rate), with the largest percentage completed by owners and/or managers (76.9\%). Most respondents classified their business as retail nursery/garden center (12.8\%), landscape design/installation (26\%), or a combination of each (32.9\%).

Introduced in 1966 by J. Frank Schmidt and Son Co., Acer rubrum 'Franksred' (Red Sunset ${ }^{\circledR}$ red maple) is thought to be the most widely used shade tree cultivar ever introduced in the United States and Canada (Kinen and Driedger 1991). Now 37 years after its introduction, Iowa nursery and landscape professionals still identify 'Franksred' as their bestselling red maple selection (60.3\%). A considerably smaller percentage of respondents identified 'Autumn Flame' (17.9\%), 'Northwood' (11.5\%), 'October Glory' (2.6\%), and the relatively new introduction 'Magnificent Magenta' (Burgundy Belle $\left.^{\circledast}\right)(1.3 \%)$ as their best-selling red maple.

Slightly more than one-half (53.8\%) of our respondents identified Princeton Nurseries' 1964 introduction, Acer saccharum 'Green Mountain', as their best-selling sugar maple selection. Dirr (1998) suggests 'Green Mountain' is actually a hybrid between sugar maple and black maple (Acer nigrum), which might account for its reported improved resistance to leaf scorch compared to species sugar maples and its favored status among nursery and landscape professionals in Iowa. The late Willet Wandell's Illinois selection 'Legacy' (15.4\%), Bailey Nurseries 'Bailsta' (Fall Fiesta $\left.^{\mathrm{TM}}\right)(10.3 \%)$, another Wandell introduction 'Commemoration' (6.4\%), and Princeton Nurseries 'Bonfire' (3.8\%) round out the top five best-selling sugar maples.

Norway maple (Acer platanoides) has been estimated as the most frequently used street tree in the United States (Nowak and Rowntree 1990), but its propensity for escaping from cultivation and competing with the native flora has, at least in the eastern United States, severely damaged the reputation of Norway maple along with its legion of cultivars (Jabco 1995; Harrington et al. 2003). Iowa's nursery and landscape professionals are aware of the potential danger posed by Norway maple, especially in some of the more heavily vegetated areas in the extreme eastern and southeastern parts of the state; however, the species remains a staple in the nursery trade. The largest percentage of respondents (33.3\%) identified the 1979 Bailey Nurseries introduction Acer platanoides 'Pond' (Emerald Lustre ${ }^{\mathrm{TM}}$ Norway maple) as their best-selling selection, followed by 'Emerald Queen' (23.1\%) and 'Deborah' (20.5\%). One of the oldest ('Crimson King') and one of the newest ('Princeton Gold') Norway maple cultivars were each mentioned by $5.1 \%$ of respondents.

Over the past 20 years, hybrids between red maple (Acer rubrum) and silver maple (Acer saccharinum), known collectively as Freeman maple (Acer $\times$ freemanii), have been thoroughly embraced by nursery professionals and their clients throughout much of the Midwest. But in Iowa, Glenn Jeffers' 1980 introduction Acer $\times$ freemanii 'Jeffersred' (Autumn Blaze ${ }^{\circledR}$ Freeman maple) has become synonymous with the name Freeman maple as evidenced by the overwhelming percentage of respondents (88.5\%) listing it as their best-selling selection. To date, the tree has proven to be a durable performer in the landscape, but its popularity was undoubtedly enhanced in 1997 when the Iowa Nursery and Landscape Association designated 'Jeffersred' the "Tree of the Year." Other excellent Freeman maple selections are available in the nursery trade; however, 'Celzam' (Celebration $^{\circledR}$ ) (2.6\%), 'DTR 102' (Autumn Fantasy ${ }^{\circledR}$ ) (2.6\%), and 'Marmo' (1.3\%) were scarcely mentioned by respondents.

A growing number of nursery and landscape professionals in the upper Midwest believe ashes (Fraxinus spp.) are over-represented in managed landscapes, but overuse is understandable after considering the ease with which members of this genus are transplanted, their tolerance to a wide range of soil conditions, robust growth rate, and desirable ornamental traits. Cultivars of white ash are particularly popular in Iowa, due in large part to their dependable and vibrant fall foliage display. The number of white ash selections found in the nursery trade has increased steadily over the past 20 years, but none have equaled the popularity and name recognition of Fraxinus americana 'Junginger' (Autumn Purple ${ }^{\circledR}$ white ash), introduced in 1956 by McKay Nursery Co., Waterloo, Wisconsin (Santamour and McArdle 1983b). As proof, almost threefourths $(73.1 \%)$ of our respondents said it was their bestselling white ash. Unfortunately, basal bark splitting on relatively young trees (usually less than 8 to $10 \mathrm{~cm}$ caliper) may undermine confidence in this popular cultivar. Surprisingly, the only other white ash mentioned was Willet Wandell's 1975 introduction 'Autumn Applause' (17.9\%).

For many years after their introduction, Fraxinus pennsylvanica 'Marshall Seedless' and 'Summit', 1955 and 1957, respectively, essentially were the only green ash cultivars sold in nurseries and garden centers, but their 
market domination began to fade in 1978 with R.H. Patmore's introduction of 'Patmore' green ash (Santamour and McArdle 1983b). Exceptionally cold-hardy and seedless, its dark green glossy leaves and a well-mannered crown captured the attention of Iowa's green industry, so much so that in our study, the majority of respondents (64.1\%) identified 'Patmore' as their best-selling selection of green ash. A fewer number of respondents listed 'Marshall Seedless' (14.1\%) and 'Summit' (14.1\%) as their best-selling green ash; however, these early cultivar pioneers remain viable choices for the Iowa landscape. It remains to be seen if more recent introductions such as 'Cimmzam' (Cimmaron ${ }^{\circledR}$ ) (2.6\%) and 'Rugby' (Prairie Spire $\left.{ }^{\circledR}\right)(1.3 \%)$ achieve the popularity of 'Patmore'.

With their 1949 introduction 'Moraine', the Siebenthaler Company of Dayton, Ohio, introduced thornless honeylocusts into the mainstream of the nursery trade (Flemer 1990). In consecutive years during the mid- to late 1950s, three additional honeylocust selections appeared on the scene: Gleditsia triacanthos var. inermis 'Suncole' (Sunburst $^{\circledR}$ ), 'PNI 2835' (Shademaster ${ }^{\circledR}$ ), and 'Skycole' $\left(\right.$ Skyline $\left.^{\circledR}\right)$, in 1955, 1956, and 1957, respectively (Santamour and McArdle 1983a). And now, almost 50 years later, our respondents identified 'Skycole' (42.3\%), 'Suncole' (26.9\%), and 'PNI 2835' (20.5\%) as the top three best-selling honeylocusts. Of course, additional selections have been released in the years between 1957 and today; however, none were mentioned by our respondents.

American linden (Tilia americana) did not garner the same enthusiasm as other species included in our questionnaire. In fact, a noteworthy percentage of respondents (21.8\%) either did not answer the question regarding American lindens or said they do not use the species. Of those offering American linden for sale, or including it in their landscape designs, Tilia americana 'Redmond' was most frequently mentioned as the best-selling cultivar (66.6\%). The popularity of 'Redmond' is truly remarkable considering that the original tree was discovered in the early 1920s by C.M. Redmond of Fremont, Nebraska, and introduced to the nursery trade in 1942 (Santamour and McArdle 1985). A much smaller percentage of respondents mentioned Tilia americana 'Boulevard' (6.4\%), 'Bailyard' (Frontyard ${ }^{\circledR}$ ) (3.8\%), and 'DTR 123' (Legend $\left.{ }^{\circledR}\right)(1.3 \%)$ as their best sellers.

Like Acer $\times$ freemanii 'Jeffersred' (Autumn Blaze ${ }^{\circledR}$ Freeman maple), our respondents overwhelmingly identified Tilia cordata 'PNI 6025' (Greenspire ${ }^{\circledR}$ littleleaf linden) as their best-selling littleleaf linden (85.9\%). Once again, name recognition and a plentiful array of suppliers have endeared this Princeton Nurseries selection to retailers and designers, but bark splitting and trunk decay have been associated with 'PNI 6025', which underscores the need to identify and use littleleaf linden cultivars resistant to this physiologic disorder (Davis and Peterson 1980). Two selections men- tioned by our respondents, Tilia cordata 'Baileyi' (Shamrock ${ }^{\circledR}$ littleleaf linden) (3.8\%) and 'Glenleven' (3.8\%), could introduce needed diversity to this important shade tree species.

If birches (Betula spp.) are to be successful in Iowa, they must be resistant to the bronze birch borer (Agrilus anxius). Therefore, it is not surprising that borer-resistant Betula nigra 'Cully' (Heritage ${ }^{\circledR}$ river birch) (48.7\%) and the species Betula nigra (10.3\%) were identified by a majority of respondents as their best-selling birch selections. Of course, neither the species river birch nor cultivar 'Cully' exhibit stark white bark that is so coveted by the gardening public, which explains the popularity of Betula populifolia 'Whitespire Sr.' (30.8\%), a gray birch with chalky-white, nonexfoliating bark and a reported "high degree of borer resistance." Unfortunately, confusion created by the introduction of more than one genotype has raised serious questions about the borer resistance of any birch sold as 'Whitespire' (Santamour and McArdle 1989).

Although the primary focus of our study was largegrowing landscape trees, we took the opportunity to update our knowledge about crabapple usage in the state. Recently, Iles and Stookey (1997) reported Malus 'Prairifire' (23.4\%), 'Spring Snow' (22.4\%), and 'Snowdrift' (14.3\%) were the best-selling crabapples in Iowa. Results from our current study show the same crabapple selections and their rank order as unchanged; however, a greater percentage of respondents now identify 'Prairifire' (61.5\%) as their bestselling crabapple, followed by the fruitless 'Spring Snow' (23.1\%) and 'Snowdrift' (2.6\%). With attractive spring flowers, persistent fruit, and reported immunity to the fungal pathogen-causing apple scab (Venturia inaequalis), it is difficult to be critical of the success enjoyed by Malus 'Prairifire' (Dayton 1982), but with hundreds of other useful crabapple taxa available in the nursery trade, it seems a prudent recommendation to temper enthusiasm for 'Prairifire' in favor of improving the diversity of crabapple cultivars used in residential and commercial landscapes.

When asked to list their top five best-selling tree selections, the largest percentage of respondents $(37.0 \%)$ said Acer $\times$ freemanii 'Jeffersred' (Autumn Blaze ${ }^{\circledR}$ Freeman maple) was their absolute best seller, and overall, it was mentioned more than any other tree (20.5\%) (Table 1). Most of the trees listed by respondents had been mentioned previously in the questionnaire; however, 21 respondents (8.4\%) listed red oak (Quercus rubra) among their top five best-selling trees.

\section{CONCLUSION}

Before the advent of the cultivar (mid- to late 1940s), most landscape trees in the nursery trade were of seedling origin, and variability within a species population could be dramatic. Cultivars have removed much of the uncertainty associated with tree purchasing by ensuring uniformity among named selections. Furthermore, interest in cultivars 
Table 1. Respondents' answer to the request, "list your top five best-selling tree selections."

\begin{tabular}{|c|c|c|c|c|c|c|}
\hline \multirow[b]{2}{*}{$\operatorname{Taxa}^{2}$} & \multirow[b]{2}{*}{$\overline{1 s t}$} & \multirow[b]{2}{*}{ 2nd } & \multicolumn{3}{|l|}{ Response (\%) } & \multirow[b]{2}{*}{ Total } \\
\hline & & & $3 \mathrm{rd}$ & 4th & 5 th & \\
\hline $\begin{array}{l}\text { Acer } \times \text { freemanii 'Jeffersred' } \\
\left(\text { Autumn Blaze }{ }^{\circledR} \text { Freeman maple) }\right.\end{array}$ & $37.0(\mathrm{n}=27)$ & $13.6(n=9)$ & $7.5(\mathrm{n}=5)$ & $4.6(n=3)$ & $10.4(n=7)$ & $20.5(n=51)$ \\
\hline $\begin{array}{l}\text { Fraxinus americana 'Junginger' } \\
\text { (Autumn Purple }{ }^{\circledR} \text { white ash) }\end{array}$ & $6.8(\mathrm{n}=5)$ & $13.6(n=9)$ & $16.4(\mathrm{n}=11)$ & $6.2(n=4)$ & $4.5(n=3)$ & $12.9(\mathrm{n}=32)$ \\
\hline $\begin{array}{l}\text { Fraxinus pennsylvanica 'Patmore' } \\
\text { (green ash) }\end{array}$ & $11.0(\mathrm{n}=8)$ & $9.1(n=6)$ & $7.5(\mathrm{n}=5)$ & $3.1(n=2)$ & $9.0(n=6)$ & $10.8(\mathrm{n}=27)$ \\
\hline $\begin{array}{l}\text { Acer rubrum 'Franksred' } \\
\text { (Red Sunset }{ }^{\oplus} \text { red maple) }\end{array}$ & $8.2(\mathrm{n}=6)$ & $13.6(\mathrm{n}=9)$ & $13.4(\mathrm{n}=9)$ & $1.5(\mathrm{n}=1)$ & $1.5(\mathrm{n}=1)$ & $10.4(n=26)$ \\
\hline Malus 'Prairifire' (crabapple) & $2.7(\mathrm{n}=2)$ & $9.1(n=6)$ & $3.0(\mathrm{n}=2)$ & $9.2(n=6)$ & $10.4(\mathrm{n}=7)$ & $9.2(n=23)$ \\
\hline Quercus rubra (red oak) & $2.7(\mathrm{n}=2)$ & $4.5(n=3)$ & $7.5(\mathrm{n}=5)$ & $10.8(n=7)$ & $6.0(n=4)$ & $8.4(n=21)$ \\
\hline Malus ‘Spring Snow’ & $5.5(n=4)$ & $1.5(\mathrm{n}=1)$ & $3.0(\mathrm{n}=2)$ & $7.7(n=5)$ & $6.0(n=4)$ & $6.4(n=16)$ \\
\hline $\begin{array}{l}\text { Tilia cordata 'PNI } 6025 \text { ' } \\
\text { (Greenspire }{ }^{\circledast} \text { littleleaf linden) }\end{array}$ & $1.4(\mathrm{n}=1)$ & $3.0(n=2)$ & $1.5(\mathrm{n}=1)$ & $9.2(n=6)$ & $4.5(n=3)$ & $5.2(\mathrm{n}=13)$ \\
\hline $\begin{array}{l}\text { Acer platanoides 'Pond' } \\
\text { (Emerald Lustre }{ }^{\mathrm{TM}} \text { Norway maple) }\end{array}$ & $4.1(n=3)$ & $4.5(n=3)$ & $1.5(\mathrm{n}=1)$ & $3.1(\mathrm{n}=2)$ & $0.0(\mathrm{n}=0)$ & $3.6(n=9)$ \\
\hline Betula nigra (river birch) & $0.0(\mathrm{n}=0)$ & $4.5(n=3)$ & $0.0(\mathrm{n}=0)$ & $3.1(n=2)$ & $3.0(\mathrm{n}=2)$ & $2.8(n=7)$ \\
\hline $\begin{array}{l}\text { Betula populifolia 'Whitespire' } \\
\text { (gray birch) }\end{array}$ & $2.7(n=2)$ & $1.5(\mathrm{n}=1)$ & $1.5(\mathrm{n}=1)$ & $3.1(n=2)$ & $1.5(\mathrm{n}=1)$ & $2.8(\mathrm{n}=7)$ \\
\hline $\begin{array}{l}\text { Fraxinus pennsylvanica 'Summit' } \\
\text { (green ash) }\end{array}$ & $1.4(\mathrm{n}=1)$ & $1.5(\mathrm{n}=1)$ & $3.0(\mathrm{n}=2)$ & $3.1(n=2)$ & $1.5(\mathrm{n}=1)$ & $2.8(\mathrm{n}=7)$ \\
\hline Cercis canadensis (redbud) & $1.4(\mathrm{n}=1)$ & $0.0(\mathrm{n}=0)$ & $1.5(\mathrm{n}=1)$ & $0.0(n=0)$ & $4.5(\mathrm{n}=3)$ & $2.1(n=5)$ \\
\hline $\begin{array}{l}\text { Gleditsia triacanthos var. inermis } \\
\text { 'Skycole' (Skyline }{ }^{\circledR} \text { honeylocust) }\end{array}$ & $\begin{array}{l}0.0(\mathrm{n}=0) \\
\mathbf{n}=\mathbf{7 3}^{\mathbf{y}}\end{array}$ & $\begin{array}{l}1.5(\mathrm{n}=1) \\
\mathbf{n}=\mathbf{6 6}\end{array}$ & $\begin{array}{l}1.5(\mathrm{n}=1) \\
\mathbf{n}=\mathbf{6 7}\end{array}$ & $\begin{array}{l}1.5(\mathrm{n}=1) \\
\mathbf{n}=\mathbf{6 5}\end{array}$ & $\begin{array}{l}3.0(\mathrm{n}=2) \\
\mathbf{n}=\mathbf{6 7}\end{array}$ & $\begin{array}{l}2.1(\mathrm{n}=5) \\
\mathbf{n}=\mathbf{2 4 9}\end{array}$ \\
\hline
\end{tabular}

${ }^{2}$ Of the taxa listed by respondents, only those mentioned a total of five or more times are included.

yTotal number of taxa listed per category.

has accelerated the search for, and introduction of, superior trees. Some would argue our dependence on cultivars has reduced genetic diversity in our landscapes and set the stage for another Dutch elm disease-like disaster, but how many landscape tree growers would be willing to return to precultivar days when a portion of their inventory might be rendered unsaleable because of inferior branching, poor fall color, or some other inherited and unexpected trait of a seedling tree? Today, hundreds of excellent landscape tree cultivars provide nursery and landscape professionals in Iowa and elsewhere the choices they need to create unique, interesting, and genetically diverse landscapes.

Ironically, the nursery industry's success in creating excellent landscape tree cultivars also might be its undoing, as popular selections like Acer $\times$ freemanii 'Jeffersred' (Autumn Blaze ${ }^{\circledR}$ Freeman maple) and Tilia cordata 'PNI 6025' (Greenspire ${ }^{\circledast}$ littleleaf linden) appear in design after design and landscape after landscape. If today's managed landscapes are, in fact, only variations on a far-too-familiar theme, with much too little genetic diversity, who should assume responsibility for reversing this trend? Should retail nursery operators take it upon themselves to prevent a disproportionate number of trees like Acer $\times$ freemanii 'Jeffersred' from being sold? Should landscape architects and designers lead the quest for greater diversity in our landscapes by specifying a wider array of tree cultivars for their projects? Or should it become the responsibility of all green-industry professionals, including academicians, to 
help consumers consciously avoid overused selections of landscape trees?

Results from our study suggest Iowa's nursery and landscape professionals, along with their many clients, have grown increasingly dependent on a relatively few flagship landscape tree cultivars. It is incumbent on green-industry professionals to acknowledge the potential for overusing several tree selections mentioned in this study and make a concerted effort to increase the variety of cultivars within a species or genera used or recommend for use. Planting the same handful of shade and flowering tree cultivars over and over again makes for bland predictability in the Iowa landscape and could potentially result in the loss of a significant percentage of our tree population should they prove susceptible to opportunistic insects, disease-causing pathogens, and/or abiotic disorders.

\section{LITERATURE CITED}

Collins, W.H. 1984. A diversified line of new trees can spark customer interest. Am. Nurseryman 160(6):81-85.

Davis, S.H., and J.L. Peterson. 1980. Trunk decay on greenspire linden. J. Arboric. 6(10):258-260.

Dayton, D.F. 1982. 'Prairifire'. HortScience. 17(2):262.

Dirr, M.A. 1975. Manual of Woody Landscape Plants: Their Identification, Ornamental Characteristics, Culture, Propagation, and Uses. Stipes, Champaign, IL.

_ 1998. Manual of Woody Landscape Plants: Their Identification, Ornamental Characteristics, Culture, Propagation, and Uses. Stipes, Champaign, IL.

Dirr, M.A., and O.M. Lindstrom. 1989. Fine-tuning the introduction process. Am. Nurseryman 169(1):47-55.

Flemer, W. 1990. American ornamentals: A historical outline of plant popularity. Am. Nurseryman 171(12):137-165.

Fromherz, K. 1999. Tracking trends. Am. Nurseryman 189(3):68-73.

Harrington, R.A., R. Kujawski, and H.D.P. Ryan. 2003. Invasive plants and the green industry. J. Arboric. 29(1):42-48.

Iles, J.K., and M.P. Widrlechner. 1992. Recommended landscape plants from the heartland. Am. Nurseryman 175(11):20-27.
Iles, J.K., and J.S. Stookey. 1997. Crabapples: Sales trends and consumer preferences in Iowa. J. Arboric. 23(3):94-99.

Jabco, J.P. 1995. The dirty dozen. Am. Nurseryman 181(7):8489.

Kinen, N., and J.J. Driedger. 1991. A tale of two trees. Am. Nurseryman. 173(9):56-59.

Nowak, D.J., and R.A. Rowntree. 1990. History and range of Norway maple. J. Arboric. 16(11):291296.

Rafter, D. 2002. Made in the shade. Digger 46(12):32-42.

Santamour, F.S. and A.J. McArdle. 1983a. Checklist of cultivars of honeylocust (Gleditsia triacanthos L.). J. Arboric. 9(9):248-252.

- 1983b. Checklist of cultivars of North American ash (Fraxinus) species. J. Arboric. 9(10):271276.

- 1985. Checklists of cultivars of linden (Tilia) species. J. Arboric. 11(5):157-164.

- 1989. Checklists of cultivars in Betula (birch). J.

Arboric. 15(7):170-176.

Acknowledgments. We gratefully acknowledge the cooperation and support of the Iowa Nursery and Landscape Association. This journal paper of the Iowa Agriculture and Home Economics Experiment Station, Ames, Iowa, Project No. 3606 was supported by Hatch Act and State of Iowa funds.

${ }^{1 *}$ Associate Professor

Department of Horticulture

106 Horticulture Hall

Iowa State University

Ames, IA 50011-1100, U.S.

iles@iastate.edu

${ }^{2}$ Undergraduate Student

Department of Horticulture

106 Horticulture Hall

Iowa State University

Ames, IA 50011-1100, U.S.

${ }^{*}$ Corresponding author. 
Résumé. Un questionnaire a été posté aux 142 membres actifs de l'Association des pépiniéristes et paysagistes de l'Iowa afin de caractériser les préférences dans les cultivars d'arbres au sein des professionnels de l'industrie et de leurs clients. Les répondants ont identifié l'Acer rubrum 'Franksred' (érable rouge Red Sunset ${ }^{\circledR}$ ), l'Acer saccharum 'Green Mountain' (érable à sucre), l'Acer platanoides 'Pond' (érable de Norvège Emerald Lustre ${ }^{\mathrm{TM}}$ ), l'Acer' freemanii 'Jeffersred' (érable Freeman Autumn Blaze ${ }^{\circledR}$ ), le Fraxinus americana 'Junginger' (frêne d'Amérique Autumn Purple ${ }^{\circledR}$ ), le Fraxinus pennsylvanica 'Patmore' (frêne rouge), le Gleditsia triacanthos var. inermis 'Skycole' (févier Skyline ${ }^{\circledR}$ ), le Tilia americana 'Redmond' (tilleul d'Amérique) et le tilia cordata 'PNI 6025' (tilleul à petites feuilles Greenspire ${ }^{\circledR}$ ) comme étant les espèces le plus vendues parmi neufs espèces d'arbres. Le Betula nigra 'Cully' (bouleau noir Heritage ${ }^{\circledR}$ ) et le Malus 'Prairiefire' (pommetier) ont été identifiés comme les cultivars les plus vendus dans chacun de leurs genres respectifs. En considérant toutes les espèces d'arbres d'ornement vendues en Iowa, nos répondants ont identifié l'Acer rubrum 'Franksred' (érable rouge Red Sunset ${ }^{\circledR}$ ) comme étant la sélection la plus vendue. Cependant, la surutilisation de ces sélections populaires pourrait s'avérer problématique si des preuves de susceptibilité sérieuses à certains insectes, maladies ou désordres abiotiques se révélaient.

Zusammenfassung. Es wurde eine Brief-Umfrage unter 142 aktiven Mitgliedern der Iowa Baumschul- und Landschaftsvereinigung durchgeführt, um die Präferenzen einiger Baumkultivare im Landschaftsbau bei der Industrie und ihren Kunden zu charakterisieren. Die Rückläufe nannten Acer rubrum 'Franksred', Acer saccharum 'Green Mountain', Acer platanoides 'Pond', Acer' freemanii 'Jeffersred', Fraxinus americana 'Junginger', Fraxinus pennsylvanica 'Patmore', Gleditsia triacanthos var. inermis
'Skycole', Tilia americana 'Redmond', und Tilia cordata 'PNI 6025 ' als die bestverkauften Kultivare unter 9 verschiedenen Baumarten. Betula nigra 'Cully' und Malus 'Prairifire' wurden als die bestverkauften Kultivare innerhalb ihrer Art identifiziert. In Anbetracht aller verkauften Landschaftsbäume in Iowa wurde von den Befragten Acer' freemanii 'Jeffersred' als generell bestverkaufter Baum genannt. Eine Übernutzung dieser populären Arten könnte Probleme bereiten, wenn diese Art sich als anfällig für gesundheitsschädigende Insekten, Krankheiten oder abiotische Faktoren erweisen sollte.

Resumen. Se envió por correo un cuestionario a todos los 142 miembros activos de la Asociación de Viveristas y Paisajistas de Iowa con el fin de caracterizar las preferencias de cultivares de árboles entre los profesionales de la industria verde y sus clientes. Las respuestas identificaron a Acer rubrum 'Franksred' (Red Sunset ${ }^{\circledR}$ red maple), Acer saccharum 'Green Mountain' (sugar maple), Acer platanoides 'Pond' (Emerald Lustre ${ }^{0}$ Norway maple), Acer' freemanii 'Jeffersred' (Autumn Blaze ${ }^{\circledR}$ Freeman maple), Fraxinus americana 'Junginger' (Autumn Purple ${ }^{\circledR}$ white ash), Fraxinus pennsylvanica 'Patmore' (green ash), Gleditsia triacanthos var. inermis 'Skycole' (Skyline ${ }^{\circledR}$ honeylocust), Tilia americana 'Redmond' (American linden), y Tilia cordata 'PNI 6025' (Greenspire ${ }^{\circledast}$ littleleaf linden) como los mejores cultivares entre nueves especies de árboles. Betula nigra 'Cully' (Heritage ${ }^{\circledast}$ river birch) y Malus 'Prairifire' (crabapple) fueron identificados como los mejores cultivares en sus respectivos géneros. Considerando todos los árboles vendidos en Iowa, los socios cuestionados identificaron al Acer 'freemanii 'Jeffersred' (Autumn Blaze ${ }^{\circledR}$ Freeman maple) como la mejor selección. El uso excesivo de estas selecciones populares, sin embargo, podría ser problemático por la susceptibilidad a plagas de insectos, enfermedades o desórdenes abióticos. 